\title{
CHARACTERIZATION AND CONCEPTUALIZATION OF A RELICT KARST AQUIFER (BILECIK, TURKEY)
}

\author{
KARAKTERIZACIJA IN KONCEPTUALIZACIJA RELIKTNEGA \\ KRAŠKEGA VODONOSNIKA (BILECIK, TURKEY)
}

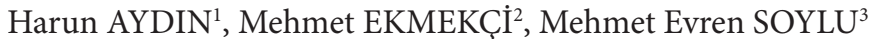

\begin{abstract}
UDC 556.33:551.44(560)
Harun Aydin, Mehmet Ekmekçi, Mehmet Evren Soylu: Characterization and conceptualization of a relict Karst aquifer (Bilecik, Turkey)

The carbonate rocks in Turkey have different hydrogeological properties as a result of controlling karstification factors, such as lithostratigraphy, source of energy gradient, tectonic activity, type of erosion base, fluctuation in sea level, and climate change in their extended areas. This study was undertaken for the characterization and conceptualization of the hydrogeological behavior of a unique example of the dissected relict karst aquifer, which is known as the Harmanköy-Beyyayla Karst System (HBKS) in Central Turkey. In order to obtain the conceptualization of the HBKS, properties of recharge, flow, storage, and discharge was analyzed. The contribution of allogenicpoint recharge to the Beyyayla and Döşkaya aquifers occurs from the Beyyayla and Tozman sinkhole with approximately $85 \%$ of total recharge. The rest of the recharge takes place as autogenic-diffuse/point type from the limestone rock-mass. The recharge on the Nardin aquifer originates from direct precipitation onto the limestone area mainly as autogenic-diffuse and, to lesser extent, as autogenic-point. Groundwater flow occurs as conduit flow at the Beyyayla and Döşkaya aquifers and as dispersed flow at the Nardin aquifer. The evaluation of all parameters shows that the HBKS can be divided into three distinct sub-catchments, namely, the Beyyayla, Döşkaya, and Nardın, while it has two different hydrogeological system so Beyyayla and Döşkaya have similar characteristics.

Keywords: Relict karst - conceptual models - hydrochemistry spring recession analysis; Turkey.
\end{abstract}

\author{
Izvleček \\ UDK 556.33:551.44(560) \\ Harun Aydin, Mehmet Ekmekçi, Mehmet Evren Soylu: Kara- \\ kterizacija in konceptualizacija reliktnega kraškega vodono- \\ snika (Bilecik, Turkey)
}

$\mathrm{Na}$ hidrogeološke lastnosti karbonatnih masivov vpliva več faktorjev, med njimi litostratigrafija, energijski gradienti, tektonska aktivnost, tip erozijske baze, spreminjanje morske gladine in klimatske spremembe. Namen te raziskave je konceptualizacija in karakterizacija zanimivega primera razkosanega reliktnega kraškega vodonosnika, znanega kot kraški sistem Harmanköy-Beyyayla (HBKS) v Centralni Turčiji. Raziskovali smo značilnosti napajanja, pretakanja, skladiščenja in praznjenja vodonosnikov. V sistem Beyyayla in Döşkaya kar 85 \% napajanja predstavlja alogeni dotok iz ponorov Beyyayla in Tozman 85 \%. Ostali del je avtogeni difuzni dotok $\mathrm{z}$ apnenčastega površja. Napajanje vodonosnika Nardin je pretežno avtogeno difuzno in v manjši meri avtogeno točkovno. V sistemu Beyyayla in Döşkaya se pretakanje vrši pretežno preko kraških kanalov, medtem ko je v vodonosniku Nardin pretakanje razpršeno. Celoten HBKS lahko razdelimo $\mathrm{v}$ tri vodozbirna območja Beyyayla, Döșkaya in Nardin, pri čemer imata Beyyayla in Döşkaya podobne hidrogeološke lastnosti.

Ključne besede: reliktni kras, konceptualni model, hidrokemija, analiza recesijske krivulje izvira, Turčija.

\footnotetext{
${ }^{1}$ Department of Environmental Engineering, Faculty of Engineering and Architecture, Yüzüncü Yıl University, Van, Turkey (e-mail: harun@yyu.edu.tr, tel: +90-432-2251024 (ext: 1141), fax: +90-432-2251732)

${ }^{2}$ International Research Center for Karst Water Resources (UKAM), Hacettepe University, Beytepe, Ankara, Turkey (ekmekci@hacettepe.edu.tr)

${ }^{3}$ Center for Sustainability and the Global Environment, University of Wisconsin, Madison, 53726, WI, USA (msoylu@wisc.edu)
}

Received/Prejeto: 14.04 .2012 


\section{INTRODUCTION}

Karstification phenomena are generally separated according to the period and processes of formation into two types as paleokarst and recent karst (Milanovic 1981). In practice, this classification is determined by geological position, geomorphologic structure, and hydrogeological properties, such as recharge, flow, storage, and discharge type of the aquifers. Paleokarst is described as a fossilized system that is completely de-coupled from the present hydrogeological system (Ford \& Williams, 1989). By contrast, recent karst is described as active karst by their manner of hydrology and hydrogeology and continues its karst evolution in present conditions. In addition, Ford and Williams (1989) mention karst areas called relict karst that are morphologically like paleokarst, but they are hydrogeologically active and modified by processes operating in the present system like recent karst.

The relict karst has two distinctive morphological and hydrogeological characteristics as compared with the other karst type. First, their hydrodynamic settings may be changed, and second, their climatic (morphogenetic) situation may be altered (Ford \& Williams 1989). In the literature, a few examples were given for relict karst such as an area of northern Puerto Rico (Monroe 1976), the Qinghai Plateau (Ford \& Williams 1989), Central Europe, the coast of the Adriatic and Black Sea (Bosak 1981), the Prealps of northern Italy (Magaldi \& Sauro 1982), and the Stone Forest of Yunnan-China (Chen et al. 1986). The recent surface morphological structure of these areas is similar to the paleokarst surface, and most parts of the karst features were eroded. Because of the weak but continued karst evolution in these aquifers, subsurface karst features are representing well developed, rounded, and well-connected channels or fracture systems.

These types of surface and subsurface karst features control the hydrodynamic properties (recharge, storage, flow, discharge) of the karst aquifer. Recharge takes place as mostly allogenic rather than autogenic. Groundwater circulation occurs in well-developed conduit systems as turbulent flow, and their springs shows a very quick and sharp response to recharge. Because of the above mentioned properties, the karst aquifer has highly heterogeneous properties. The anisotropy and heterogeneity of karst systems, however, makes the acquisition of such as very difficult, as standard hydrogeological investigation techniques are often of limited value.

Many studies have been conducted to point out hydrodynamic properties of karst aquifers. For example, recharge may occur as either allogenic or autogenic in concentrated or diffuse forms (Jakucs 1959; Schuster \& White 1971; Ternan 1972; Smart \& Hobbs 1986; Hess \& White 1988; Dreiss 1989; Martin \& Dean 1999; Lee \&
Krothe 2001; Martin \& Screaton 2001; Martin \& Dean 2001; White 2003; Screaton et al. 2004); Storage is also a property of the vadose zone as well as the phreatic zone (Mangin 1973; Kiraly \& Morel 1976; Kiraly 2002; Dörfliger et al. 2009), and flow may have a character of concentrated, dispersed, or a combination of those endmembers (White \& Schmidt 1966; White 1969; Schuster \& White 1971; Quinlan et al. 1996; Halihan et al. 1998; Worthington 1999; Screaton et al. 2004; Abigail et al. 2012). The complex structure of the karst aquifer makes direct determination of physical parameters related to these properties almost impossible. Thus, the black-box approach (Berkaloff 1967; Bagaric 1978; Atkinson 1977; Bear 1979; Milanovic 1981; Ford \& Williams 1989) in analyzing karst aquifers provides a useful tool to understand the hydrodynamic behavior of the aquifer based upon the tracer tests and hydrograph-chemograph analysis of the springs' discharge from the aquifer of interest (Schuster \& White 1971; Smart \& Hobbs 1986; Raeisi \& Karami 1997; White 2003; Valdes et al. 2005; Geyer et al. 2007; Göppert \& Goldscheider 2008; Özyurt 2008; Özyurt \& Bayar1 2008; Bayarı et al. 2011; Abigail et al. 2012).

Turkey, with its great variety of problems related to karst, is perhaps the most challenging country for the karstologist and hydrogeologist. Carbonate rocks extend over approximately one-third of Turkey's surface area, belonging to the Mediterranean part of the Alpine and Himalayan collisional events orogenic belt (Eroskay \& Günay 1979; Ford \& Williams 1989). The non-uniformity and heterogeneity of the geological, geographical, and therefore hydrogeological settings account for the large diversity of karst types identified over the territory (Eroskay \& Günay 1979; Elhatip 1997; Ekmekçi 2003; Ekmekçi \& Nazik 2004). These rocks have different hydrogeological properties as a result of factors that control karstification in the extending area such as lithostratigraphy, source of energy gradient, tectonic activity, type of erosion base, fluctuation in sea level, and climate change. Ekmekçi (2003) states that the evolution of karsts in Turkey occurs in two groups: rejuvenated karst and evolutionary karst. A rejuvenated karst is distinguished by younger karst features that develop within older but interrupted karsts (paleokarst). An evolutionary karst indicates that karstification processes have been effective without interruption and includes all types of karsts from juvenile to relict. The evolutionary karst dominates in the Western Central Anatolian Region (WCAR) of Turkey. The karstification in this region has distinctive characteristics compared with other karst regions of Turkey, because of the different neotectonic regime, absence 
of cover deposits, relatively shallow impervious units, dissection of carbonate rocks, etc. Thus in the WCAR, karstification processes have been continuous since Miocene without any interruption up to today. These are the reason of having relict karst aquifers in the WCAR. In addition with respect to the low storage capacity, this aquifer is important for urban and irrigation water supply in semi-arid regions.

Numerous articles have been published about characterization and conceptualization of the karst aquifers in Turkey. However, there has not yet been any study of dissected relict karst types. Therefore, the results of this study make an important contribution to the literature. The specific objectives of this study were to (1) use some physical and chemical properties of the surface water and groundwater to determine recharge, flow, storage, and discharge components for the dissected relict karst aquifer and (2) to develop a conceptual model of the system.

\section{STUDY AREA}

The study area is located in the northern part of the Central Anatolia Province (CAP-E), an area is also called the Western Central Anatolian Region (WCAR) and it has a different neotectonic regime (Şengör et al. 1985) and paleogeographical development. According to Ekmekçi (2003), the limestone extending in the WCAR contains a unique example of evolutionary dissected relict karst types in Turkey (Fig. 1). The evolution of the dissected relict karst in the region has been mainly controlled by the high energy gradient, change of neotectonic regime, entrenchment of major rivers, absence of cover deposits and change in energy gradient. The source for energy gradient since Pleistocene is the fluctuation of the Black Sea level. Svitoch et al. (2000) and Kislov and Toropov (2007) claimed that the Black Sea level fluctuated since Pleistocene between $150 \mathrm{~m}$ bsl. and $200 \mathrm{~m}$ bsl. from present sea level.

On the other hand Ekmekçi (2003) stated that in Early Miocene, Central Anatolia was elevated above the contemporary sea level up to $2000 \mathrm{~m}$ and during Late Miocene when a drastic change occurred between the northern and southern part of Central Anatolia. During Late Miocene, the southern part was flooded by fresh waters and effects of flooding gradually diminished northward. The most northern part, including the Sakarya River basin, continued to expose to atmospheric conditions. By the end of the Pliocene, karst in carbonate rock masses was well developed (Ekmekçi \& Nazik 2004). Due to the westerly escape of the Anatolian Scholle after the intersection of the North Anatolia Fault (NAF) and East Anatolia Fault (EAF), a transition zone between the Aegean Graben system in the west and the tectonically weak Central Anatolian 'Ova' Regime in the east was developed (Şengör et al. 1985). This tectonic regime sliced up the northern region during Pleistocene which was resulted in drastic changes of drainage.
The study area is drained mainly by the Sakarya River which is discharging into the Black Sea. Thought that the fluctuation of Black Sea level and change in neotectonic regime results the evolution of drainage system, incision of Sakarya River and change of energy gradient around the study area. Karstification processes have been continuous since Miocene without any interruption up to today in the WCAR. Another consequence linked to this tectonic regime and sea level change where the dissection of large carbonate rocks that were formerly karstified into smaller pieces. The modern appearance of karst in the WCAR can be defined as 'dissected-relict' karst. Currently in the WCAR, the dissected relict karst occurs in enormous volume despite its smaller dimensions (Fig. 1).

Because of the above mentioned properties for the WCAR, karst features such as dolines, poljes, and uvalas have been eroding, an occurrence that is mainly controlled by the incision of the Sakarya River. Thus, the evolution of drainage system affects the hydrodynamic properties of the dissected relict karst aquifer in the region. As another note, the area has karst springs that discharge a few hundreds of liters per second during the winter and the spring; the discharge decreases gradually to a few liters per second or even run dry during the rest of the year.

This research was conducted on a limestone block extending between the Harmanköy and Beyyayla villages in the WCAR. One of the largest parts of the dissected relict karst aquifer in the WCAR is known as the Harmanköy - Beyyayla Karst System (HBKS). The HBKS forms the highlands in the WCAR that is located between the Sarıcakaya and Yenipazar districts from the north to the south and the Beyyayla and Harmanköy villages from the east to the west. It has a rectangular shape with a surface area of $49.5 \mathrm{~km}^{2}$. The HBKS is elongated east to west with a longer axis of about $22 \mathrm{~km}$; the shorter axis is 


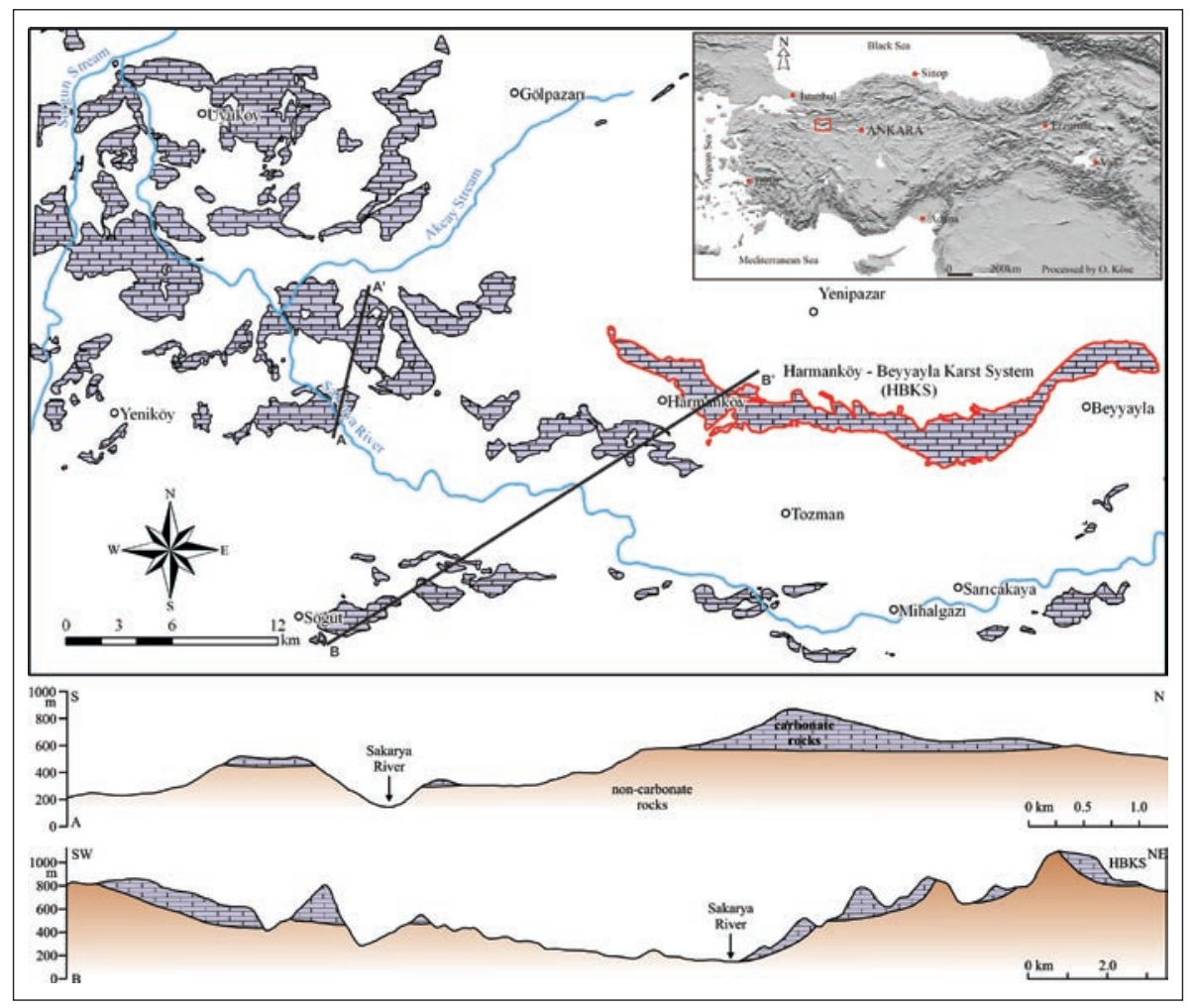

Fig. 1: Location map of the study area and dissected relict karst areas in north western Turkey.

$2.25 \mathrm{~km}$. Its average elevation is $1150 \mathrm{~m}$ asl. (Fig. 1). The study area is dominated by a transition of Anatolia terrestrial type climate and Black Sea type climate with hot and dry summers and cold and wet winters. The mean annual precipitation observed at the study area and $\mathrm{Bi}$ lecik meteorological station are $621.0 \mathrm{~mm}$ (between 2003 and 2004) and $454.2 \mathrm{~mm}$ (between 1970 and 2011), respectively. Long-term mean annual air temperature in the Bilecik meteorological station is $12.5^{\circ} \mathrm{C}$, and the minimum and maximum average temperatures are observed in January $\left(-0.3^{\circ} \mathrm{C}\right)$ and July-August $\left(28.5^{\circ} \mathrm{C}\right)$, respectively (State Meteorological Organization of Turkey 2012). The climate around the study area is semi-arid - less humid according to Şensoy et al. (2008).

\section{SPECIFICATIONS OF THE HARMANKÖY-BEYYAYLA KARST SYSTEM}

\section{GEOLOGY AND GEOMORPHOLOGY OF THE HBKS}

The geological structure of the HBKS is evaluated from studies by Granit and Tintant (1960), Saner (1980), Altiner et al. (1991), Akyazi et al. (2001), Aksay and Duru (2002), and Gedik and Aksay (2002). The simplified geological and geomorphologic map of the study area and cross-sections are given in Fig. 2a-b and Fig. 3, respectively. The re-crystallized and cherty carbonate rocks that form the HBKS are known as Jurassic Age Bilecik Limestone Granit \& Tintant (1960). Electrical sounding studies (Aydın, 2005) and field observations show that Bilecik Limestone has a thickness of approximately $100 \mathrm{~m}$ of karstified layers and then a fractured layer. The Jurassic- and Cretaceous-Aged units in the study area are characterized by Göncüoğlu et al. (1996) as "paraauthocthonous" cover that overlay the metamorphic basement.

Karstification of the Jurassic age carbonate rock masses cropping out at the Western Central Anatolia Region is attributed to pre-Pliocene periods when terrestrial-erosional faces has dominated the region (Ekmekçi \& Nazik 2004; Tuncer 2004). The northwestern part of the country exhibits a distinct type of karst owing to the different neotectonic regime and the coeval paleogeographical development. Emplacement and rapid incision of the Sakarya river, associated with a weak but continues continental uplift has drastically changed the surface and consequently subsurface drainage. Re-orientation of the surface drainage has dissected the large karstic 


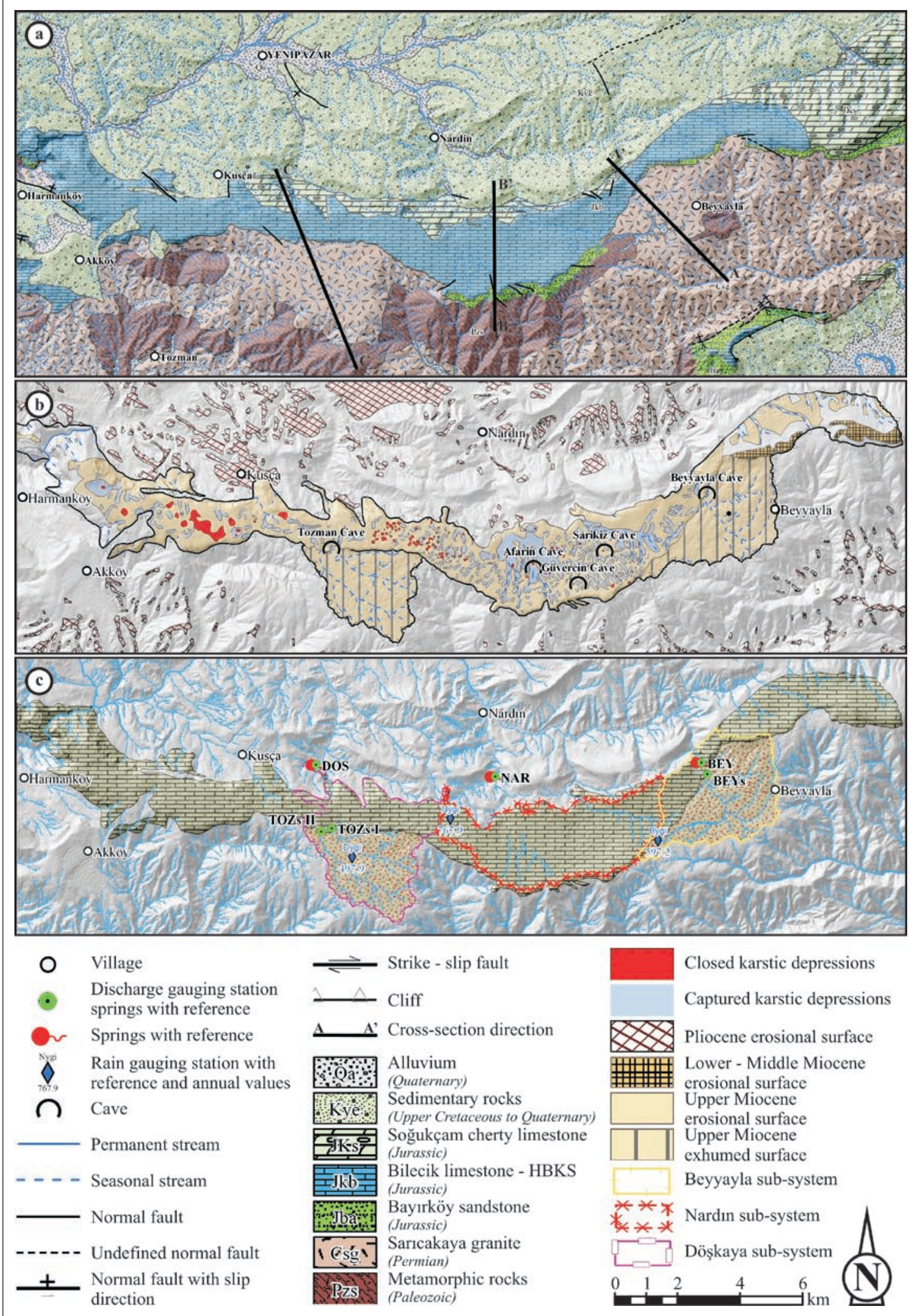

Fig. 2: (a) Geological (modified from Aksay and Duru, 2002 and Gedik and Aksay, 2002), (b) geomorphological and (c) hydrological maps of the study area. 


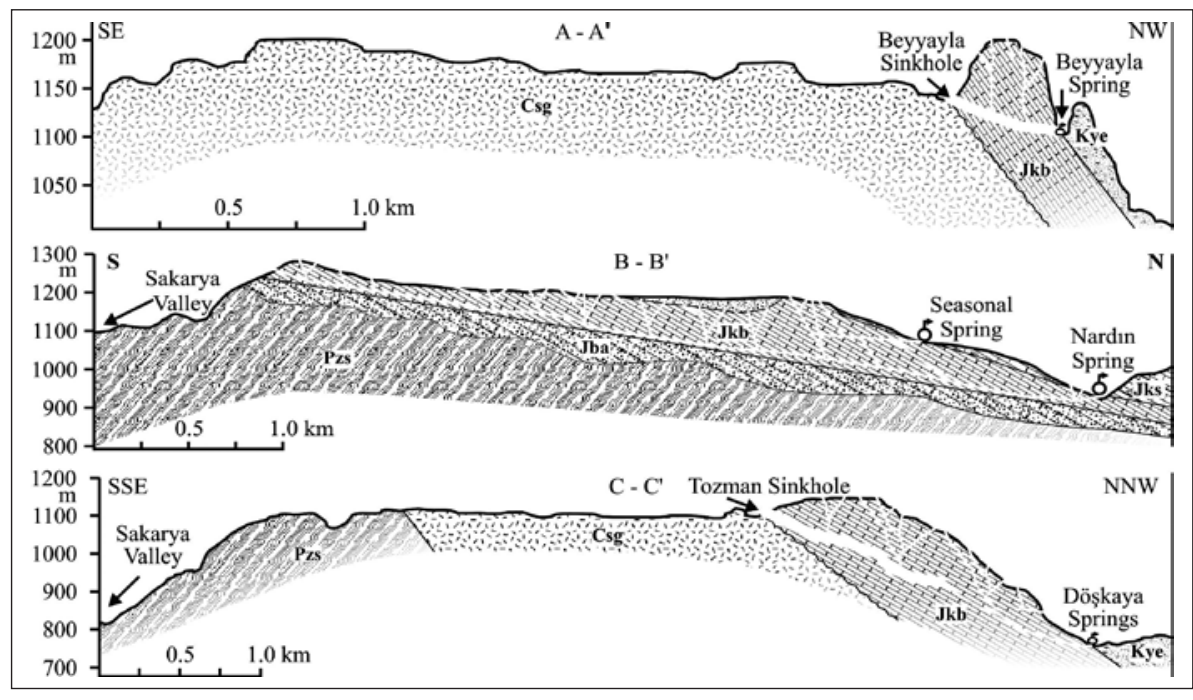

Fig. 3: Geological cross-sections of HBKS (description of abbreviations and cross-section directions are given in Fig. 2).

carbonate masses which were uplifted and significantly eroded. Dissection by streams and rivers has reduced the size and the continuity while the uplift has resulted in reduction in the thickness of the carbonate rock-masses (Fig. 2b; Nazik et al. 2001; Ekmekçi \& Nazik 2004). Ekmekçi (2003) defines the modern appearance of karst in the WCAR as "dissected relict" karst.

Nazik et al. (2001) and Tuncer (2004) describe the modern geomorphologic appearance of the HBKS as Upper Miocene erosional surface. A total of 357 karstic depressions (Aydin 2005) and 5 caves (Nazik et al. 2001) were identified in the HBKS (Fig. 2b). Because of the above mentioned reasons, most of the karstic depressions (269) such as dolines, poljes, and uvalas have been capturing by the surface drainage like as a temporary stream. In addition, according to White's (1988) classification, two caves known as Tozman and Beyyayla sinkholes have formed a "angulate passage" in the HBKS with a length and depth of about $770 \mathrm{~m}$ and $438 \mathrm{~m}$ and $-70 \mathrm{~m}$ and $-26 \mathrm{~m}$, respectively. The Beyyayla sinkhole has one entrance, and the Tozman sinkhole has two entrances. GIS-based morphometric analysis shows that the HBKS consists of three different surface morphologies, namely, the Beyyayla, Döşkaya, and Nardın (Aydın 2005). Beyyayla and Döşkaya subsections located on the east and west sides of the HBKS have similar geomorphologic properties such as depression density, pitting index, circularity index, etc. On the other hand, the Nardin subsection is located in the middle of these two subsystems and possesses different geomorphologic properties.

\section{HYDROLOGY AND HYDROGEOLOGY OF THE HBKS}

Bilecik Limestone is very karstified, which enables the circulation and accumulation of groundwater in the HBKS. Three sinking streams, drain surface water from granite rocks on the southern part of the HBKS (Fig. 2c). These streams make main allogenic point recharge to the HBKS. In addition, these streams are recharging to HBKS with lower than $10 \mathrm{l} / \mathrm{s}$ about five months in the year. Thus, the discharge of these streams are controlling quantity and quality of the spring water that discharging from the Beyyayla and Döşkaya springs. The Beyyayla stream (BEYs) sinks underground at the entrance of the Beyyayla sinkhole with a mean annual discharge of 50.5 l/s on the east side of the HBKS (Tab. 1). The Tozman-I (TOZs I) and Tozman-II (TOZs II) streams feed the HBKS at the two entrances of the Tozman sinkhole with a total average discharge of $49.2 \mathrm{l} / \mathrm{s}$ at the west side of the HBKS. The drainage area of the Beyyayla and Tozman streams was determined as $8.3 \mathrm{~km}^{2}$ and $7.2 \mathrm{~km}^{2}$, respectively. These streams create allogenic-point recharge to the HBKS. Groundwater from the Bilecik Limestone aquifer discharges from three large and eight small springs at the north flank of the HBKS (Fig. 2c). One of the biggest springs is called the Beyyayla (BEY) spring, which emerges from the outlet of a Beyyayla sinkhole on the east part of the HBKS. The minimum and maximum discharge of the Beyyayla spring is $1 \mathrm{l} / \mathrm{s}$ and $345.4 \mathrm{l} / \mathrm{s}$.

The watersheds of the Beyyayla spring consist of limestone and granite as $2.8 \mathrm{~km}^{2}$ and $8.3 \mathrm{~km}^{2}$, respectively. The Döşkaya (DOS) spring emerges west of the aquifer with a minimum and maximum discharge of $1.5 \mathrm{l} / \mathrm{s}$ and $208.9 \mathrm{l} / \mathrm{s}$. The watersheds of the Döşkaya spring contain limestone and granite as $5.3 \mathrm{~km}^{2}$ and $7.2 \mathrm{~km}^{2}$, respectively. The other large spring called the Nardin (NAR) spring emerges from the middle of these two springs; all of the drainage area is covered by limestone $\left(20 \mathrm{~km}^{2}\right)$. This spring has a maximum discharge of $395.8 \mathrm{l} / \mathrm{s}$, and is drying out in the year. The elevations of the Beyyayla, Nardin, and Döşkaya springs are 1119 m, 926 m, and $801 \mathrm{~m}$ asl., respectively. All of the sampled spring wa- 
Tab. 1: Elevation, average, minimum, maximum, standard deviation and coefficient of variation of some physical and chemical properties and discharge of surface and groundwater.

\begin{tabular}{|c|c|c|c|c|c|c|c|c|c|}
\hline & Code & $\begin{array}{c}T \\
\left({ }^{\circ} \mathrm{C}\right)\end{array}$ & $p H$ & $\begin{array}{c}S p C \\
(\mu S / \mathrm{cm})\end{array}$ & $\begin{array}{c}C a \\
(m e q / I)\end{array}$ & $\begin{array}{c}\mathrm{HCO}_{3} \\
\text { (meq/I) }\end{array}$ & $\begin{array}{c}Q_{s} \\
(L / s)\end{array}$ & $\begin{array}{c}Q_{R} \\
(L / s)\end{array}$ & Description \\
\hline \multirow{6}{*}{$\stackrel{n}{\breve{m}}$} & $\mathrm{n}$ & & & & 22 & & & & \multirow{6}{*}{$\begin{array}{l}\text { Sinking Stream } \\
\text { at Beyyayla } \\
\text { Subsystem } \\
\text { (1160 m asl.) }\end{array}$} \\
\hline & Average & 12.24 & 8.04 & 436.5 & 2.766 & 2.999 & - & 50.5 & \\
\hline & Min & 0.15 & 7.60 & 237.8 & 1.802 & 2.050 & - & 0.2 & \\
\hline & Max & 23.30 & 8.36 & 722.1 & 3.918 & 4.703 & - & 295.3 & \\
\hline & SD & 7.48 & 0.27 & 146.7 & 0.706 & 0.759 & - & 82.8 & \\
\hline & VC (\%) & 61.1 & 3.3 & 33.6 & 25.5 & 25.3 & - & 164.0 & \\
\hline \multirow{6}{*}{ 岕 } & $\mathrm{n}$ & & & & 22 & & & & \multirow{6}{*}{$\begin{array}{l}\text { Beyyayla Spring } \\
\text { (1119 m asl.) }\end{array}$} \\
\hline & Average & 9.75 & 7.52 & 553.3 & 4.079 & 4.192 & 59.6 & - & \\
\hline & Min & 5.87 & 6.90 & 328.6 & 2.695 & 2.850 & 1.0 & - & \\
\hline & Max & 14.60 & 7.80 & 844.6 & 5.873 & 5.891 & 345.4 & - & \\
\hline & SD & 2.86 & 0.29 & 162.7 & 1.149 & 1.088 & 96.5 & - & \\
\hline & VC (\%) & 29.3 & 3.9 & 29.4 & 28.2 & 26.0 & 161.8 & - & \\
\hline \multirow{6}{*}{$\begin{array}{l}\text { Ñ } \\
\stackrel{0}{L}\end{array}$} & $\mathrm{n}$ & & & & 12 & & & & \multirow{6}{*}{$\begin{array}{l}\text { Sinking Strean } \\
\text { at Döșkaya } \\
\text { Subsystem } \\
\text { (1100 m asl.) }\end{array}$} \\
\hline & Average & 9.58 & 7.76 & 232.1 & 1.581 & 1.863 & - & 49.2 & \\
\hline & Min & 0.00 & 7.35 & 62.2 & 0.733 & 0.856 & - & 0.1 & \\
\hline & Max & 20.65 & 8.09 & 474.0 & 4.027 & 3.571 & - & 180.9 & \\
\hline & SD & 7.97 & 0.23 & 138.2 & 1.048 & 0.809 & - & 61.7 & \\
\hline & VC (\%) & 83.2 & 3.0 & 59.6 & 66.3 & 43.4 & - & 125.5 & \\
\hline \multirow{6}{*}{ Øิ } & $\mathrm{n}$ & & & & 22 & & & & \multirow{6}{*}{$\begin{array}{l}\text { Döșkaya Spring } \\
\text { (801 m asl.) }\end{array}$} \\
\hline & Average & 9.41 & 7.24 & 719.6 & 5.214 & 5.199 & 41.8 & - & \\
\hline & Min & 5.00 & 6.84 & 249.4 & 2.206 & 2.426 & 1.5 & - & \\
\hline & Max & 11.30 & 7.88 & 1110.9 & 8.389 & 8.119 & 208.9 & - & \\
\hline & SD & 2.29 & 0.32 & 309.1 & 2.259 & 2.083 & 61.8 & - & \\
\hline & VC (\%) & 24.3 & 4.5 & 43.0 & 43.3 & 40.1 & 147.7 & - & \\
\hline \multirow{6}{*}{ 奂 } & $\mathrm{n}$ & & & & 15 & & & & \multirow{6}{*}{$\begin{array}{l}\text { Nardin Spring } \\
\text { (926 m asl.) }\end{array}$} \\
\hline & Average & 15.65 & 6.89 & 744.1 & 6.440 & 6.333 & 160.0 & - & \\
\hline & Min & 13.70 & 6.38 & 615.9 & 5.585 & 5.857 & dry & - & \\
\hline & Max & 17.07 & 7.18 & 833.5 & 7.017 & 6.850 & 395.8 & - & \\
\hline & SD & 1.06 & 0.25 & 83.9 & 0.456 & 0.285 & 119.8 & - & \\
\hline & VC (\%) & 6.8 & 3.7 & 11.3 & 7.1 & 4.5 & 74.9 & - & \\
\hline
\end{tabular}

$\mathrm{n}$ : number of observation; $\mathrm{Q}_{\mathrm{S}}$ : spring discharge; $\mathrm{Q}_{\mathrm{R}}$ : sinking discharge; VC: coeficient of variation

ters are $\mathrm{CaHCO}_{3}$ type. The Nardin spring's groundwater provides a good chemical quality for urban supply as opposed to the Beyyayla and Döşkaya springs' groundwater, due to settlements and allogenic point recharge in the drainage areas of Beyyayla and Döşkaya springs. Tab. 1 shows the elevations and, average, minimum, and maximum, standard deviation, and coefficient of varia- tion of some physical and chemical properties and discharge of three main springs and sinking streams. The other eight small springs flow for approximately two or three months with a discharge of about one or two $1 / \mathrm{s}$ after the wet season.

The hydrogeological relationship between the spring responses versus inputs at the Beyyayla and Döşkaya 
aquifers, two tracer tests were conducted using fluorescein in April 2004 (Aydin 2005). Groundwater velocities were calculated as $2246.4 \mathrm{~m} /$ day for the Beyyayla aquifer and $259.2 \mathrm{~m} /$ day for the Döşkaya aquifer. Further, Reynolds Numbers were determined as 27648 and 10480 for the Beyyayla and Döşkaya aquifers, respectively. In addition the recovery of tracer at Beyyayla and Döşkaya aquifer are obtained as $95.7 \%$ and $94.6 \%$, respectively. These results point out that groundwater flows in turbulent flows in the conduit networks of the Beyyayla and Döşkaya aquifers. The tracer tests also proved that there is no interaction between these aquifers in HBKS; they are isolated hydrogeologically.

\section{STUDY METHODS}

Hydrogeological characterization and conceptualization of the HBKS were developed based on the physical parameters (geology, tectonic, morphology, etc.) and dynamic properties (water chemistry, precipitation regime, infiltration, recharge, flow, storage, etc.). The field study was performed from April 2003 to November 2004 to determine the mentioned properties of the HBKS and its aquifer. First, preliminary field exploration was conducted with the aid of a 1/25000 scaled topographic base map and a handheld Global Positioning System (GPS) device. During the first field study, sampling and observation locations within the study area (i.e., springs, rain gauge station, and discharge point) were designated and marked on the base map. In addition, morphologic and speleological investigations were applied to obtain information on the surface and underground morphology of the system along the field studies. All of the observation and measurement locations and their spatial coordinates were determined by the GPS and recorded in the Geographic Information System (GIS) database for analysis and visualization in a GIS environment.

Precipitation was recorded on a total monthly basis by three pluviometers that were installed on the outcrop for the determination of precipitation regime and its amounts. The pluviometers were installed on the Beyyayla, Nardın, and Döşkaya springs' drainage area. The amount of monthly total precipitation was collected with 20 lt plastic bin that buried approximately $1 \mathrm{~m}$ below the ground. Evaporation was prevented by oil that has one centimeter height at the bottom surface of the bin. By the precipitation measurement, discharge from three sinking rivers was measured at the entrance of the Beyyayla (BEYs) and Tozman (TOZs) sinkholes, and the spring flow rate was also measured at the three main springs (Beyyayla, Nardın, and Döşkaya) by a A.OTT Kempten current meter, again on a monthly basis. Also spring recession analysis proposed by Maillet (1905) was used for estimation of dynamic properties of HBKS aquifer's.

In-situ physical and chemical measurements and sampling were also performed on site and include instant measurements of $\mathrm{pH}$, temperature $(\mathrm{T})$, and electrical conductivity (EC) via the Hydrolab Quanta-G Series Water Quality Monitoring System with an accuracy of \pm 0.2 units, $\pm 0.2^{\circ} \mathrm{C}$, and $\pm 1 \% \mu \mathrm{S} / \mathrm{cm}$, respectively. All water samples were collected from the main springs and sinking rivers on a monthly basis. Water samples were collected in a double-capped polyethylene bottles, which had been pre-cleaned three times in-situ. The samples were kept cool until analysis, which was carried out in the laboratory within 24 hours. Calcium ion was analyzed by ion chromatography (IC), and bicarbonate was determined by titration in the laboratory. All of the samples were analyzed in the Water Chemistry Laboratory of the Hacettepe University. All samples had ionic balance errors less than $\pm 5 \%$. Determination of the on-site measurements and ion composition of water samples was carried out by means of Standard Methods (APHA/ AWWA/WPCF 1989).

\section{RESULTS AND DISCUSSION}

\section{TEMPORAL VARIATION OF GROUNDWATER FLOW AND CHEMISTRY}

The physicochemical data for the surface and groundwater that were taken from the study area over the ob- servation period are given in Tab. 1. The groundwater temperature, specific conductance, and discharge of the Beyyayla, Döşkaya and Nardın springs were evaluated together with the discharge of the sinking streams 

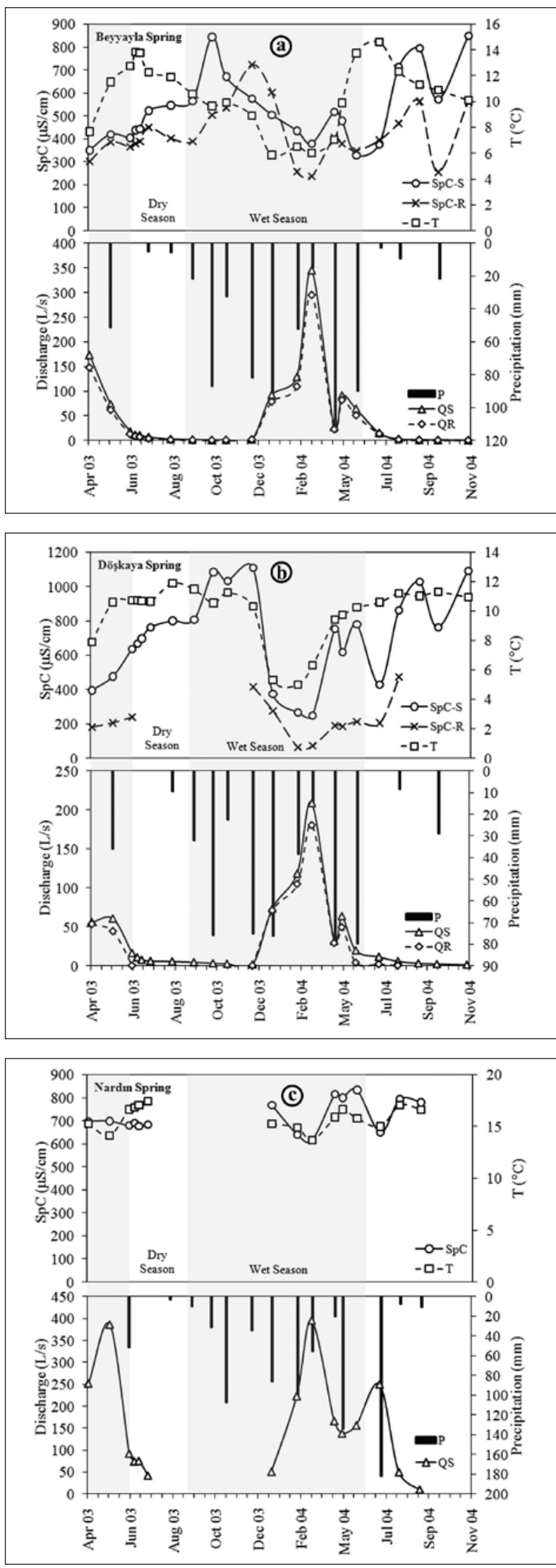

(BEYs and TOZs I + TOZs II) as hydrographs to understand a response of the systems against the inputs (Fig. $4 a-b-c)$. The discharges of main springs increased rapidly in flow (from 0 to several hundred of $1 / \mathrm{s}$ ) during a period of rainfall episodes in the HBKS. The Beyyayla and Döşkaya springs' groundwater discharge increased with the increasing sinking stream discharges during rainfall episodes (Fig. 4a-b). There is a good correlation obtained with spring discharges and sinking streams discharge on the Beyyayla and Döşkaya spring aquifer.

The Beyyayla and Döşkaya springs' groundwater displayed a rapid variation in groundwater temperature, specific conductance, and discharge, factors mainly affected by the magnitude of changes in the hydrological event in recharge type (allogenic point recharge). The recharge from sinking streams are playing an important role on the quantity and quality of the Beyyayla and Döşkaya springs' water. The discharge of these streams decreases to under $10 \mathrm{l} / \mathrm{s}$ around five months in the year. Because of that, the groundwater temperature and specific conductance at both springs were obtained as the highest values when the spring discharges were observed at a minimum (Tab. 1; Fig. 4a-b). After a few months of increasing spring discharge, the groundwater temperature and specific conductance sharply decreased. This behavior in the Beyyayla and Döşkaya springs aquifer could be explained by exchange of conduits and matrix flow conditions according to the literature data (Atkinson 1977; Martin \& Dean 2001; Martin \& Screaton 2001; Dörfliger et al. 2009; Abigail et al. 2012). The exchange of flow conditions in the Beyyayla and Döşkaya aquifers takes place as a hydrological event between the pre-event water and event water. Before the rainfall episode in the Beyyayla and Döşkaya aquifers, a small volume of the water is retained and stored in the base of the epikarst zone. This water slowly seeps through tiny fracture systems and diffusely recharges the Beyyayla and Döşkaya aquifers. At this stage, groundwater has adequate time for water-rock interactions, so groundwater temperature and specific conductance yield higher values than a rainfall episode in both aquifers (Tab. 1). When allogenicpoint recharge takes place in the Beyyayla and Döşkaya aquifers, a large volume of the water (sinking river) rapidly feeds the well-developed karst conduit network in the aquifers in which the conduit flow forms. Thought that when the conduit flow occurs in the Beyyayla and

Fig. 4: Temporal variation of surface and groundwater flow and chemistry and monthly total precipitation of (a) Beyyayla, (b) Döşkaya and (c) Nardın sub-system. 
Tab. 2: Summary of April 2004 storm at Döşkaya spring.

\begin{tabular}{|c|c|c|c|c|c|}
\hline Parermeters & $n$ & Minimum & Mean & Maximum & $C V$ \\
\hline Temperature $\left({ }^{\circ} \mathrm{C}\right)$ & 115 & 9.29 & 9.59 & 9.81 & 1.46 \\
\hline $\mathrm{pH}$ & 115 & 7.02 & 7.07 & 7.12 & 0.47 \\
\hline Electrical conductivity $(\mu \mathrm{S} / \mathrm{cm})$ & 115 & 406 & 455 & 485 & 5.31 \\
\hline Precipitation (mm) & 4 & 2.0 & 8.1 & 12.4 & 54.6 \\
\hline Discharge (l/s) & 18 & 26.8 & 62.1 & 108.5 & 39.8 \\
\hline Start of precipitation & \multicolumn{2}{|l|}{ End of precipitation } & $\begin{array}{c}\text { Duration of precipitation } \\
\text { (hour) }\end{array}$ & \multicolumn{2}{|c|}{$\begin{array}{l}\text { Amount of precipitation } \\
(\mathrm{mm})\end{array}$} \\
\hline $21.04 .2004 \quad 17: 00$ & $22.04 .200408: 00$ & & 15.00 & \multicolumn{2}{|c|}{9.9} \\
\hline $27.04 .2004 \quad 11: 00$ & $27.04 .2004 \quad 15: 00$ & & 4.75 & \multicolumn{2}{|c|}{8.2} \\
\hline $27.04 .2004 \quad 17: 30$ & 27.04.2004 18:00 & & 0.58 & \multicolumn{2}{|c|}{2.0} \\
\hline $28.04 .2004 \quad 00: 45$ & 28.04.2004 14:00 & & 13.75 & \multicolumn{2}{|c|}{12.4} \\
\hline
\end{tabular}

Döşkaya aquifers, hydraulic pressure of the well-developed conduit network becomes higher than that of tiny fracture systems of the rock blocks. After the inversion of the hydraulic pressure, the remaining water in the tiny fracture systems of the rock blocks feed the Beyyayla and Döşkaya aquifers as a diffuse flow. Furthermore, karst aquifers consist of a combination of diffuse and conduit flows (Atkinson 1977; Martin \& Screaton 2001). The dominant type of recharge on the karst system could affect the flow conditions in the aquifer and thus the quality of the discharge water. When the lack of the allogenic recharge on the HBKS, specific conductance of the spring waters tends to increase. This kind of changes in flow conditions might result in variation of water quality and increase the average values that given in Tab. 1. Similar findings were also reported in the literature (Martin \& Dean 2001; Martin \& Screaton 2001; Abigail et al. 2012).

A more detailed examination of the Döşkaya spring reveals that this spring response very rapid to recharge that was observed storms occurred on April 21 - 29, 2004. During this storm event some physicochemical parameters of groundwater and precipitation was measured continuously (Tab. 2). The chemograph of the Döşkaya spring (Fig. 5) shows that, the temperature, $\mathrm{pH}$ and electrical conductivity of spring water increased significantly while the discharge rate decreased until the April 27 storm. After the 5 hours from start of the first storm event, the physicochemical parameters started to decrease with increasing discharge. This was interpreted as dilution of the matrix water with a lower concentration of the recharge water from sinking stream (Tozman sinkhole), and concluding that the recharge water first flushed the system storage water before arriving at the outlet itself. Than second and third storm events take place on April 27 and 28. At this stage, groundwater discharge from Döşkaya spring with low conductivity and high temperature rather than first storm event. The minimum conductivity intersects with the maximum discharge. This is interpreted as dilution of the lowerconcentration groundwater that stored karstic channels from the first storm event. A similar result that observed first storm event was obtained at second and especially third storm event (Fig. 5). This chemograph analysis indicates that, Döşkaya spring gives very quick response to recharge.

On the other hand, physical and chemical properties of the Nardin spring's groundwater remained approximately constant throughout the observation period (Fig. 4c). Recharge takes place mainly as an autogenic -diffuse/point form on the aquifer. This type of recharge occurs through openings, such as sinkholes, cracks, fissures, and zones of weakness in soluble bedrocks. Autogenic diffuse/point recharge cause longer groundwater residence time in the karst aquifer rather than allogenicpoint recharge as mentioned by Wicks (1997). Therefore, groundwater in the Nardın aquifer has adequate time for water-rock interactions. Consequently, chemical properties of the Nardin spring's groundwater show approximately constant values during the year.

\section{RECHARGE ON THE HBKS}

The amount of total annual precipitation was measured for the Beyyayla, Nardın and Döşkaya springs' drainage area as 597.2, 767.9, and $497.9 \mathrm{~mm}$, respectively, between October 2003 and September 2004 (Fig. 4a-b-b). The source of recharge on the HBKS changes between two end points as autogenic to allogenic. The recharge occurs on the Beyyayla and Döşkaya springs drainage area as mainly allogenic-point recharge that happens at the drainage areas of the sinking streams (BEYs and TOZs 


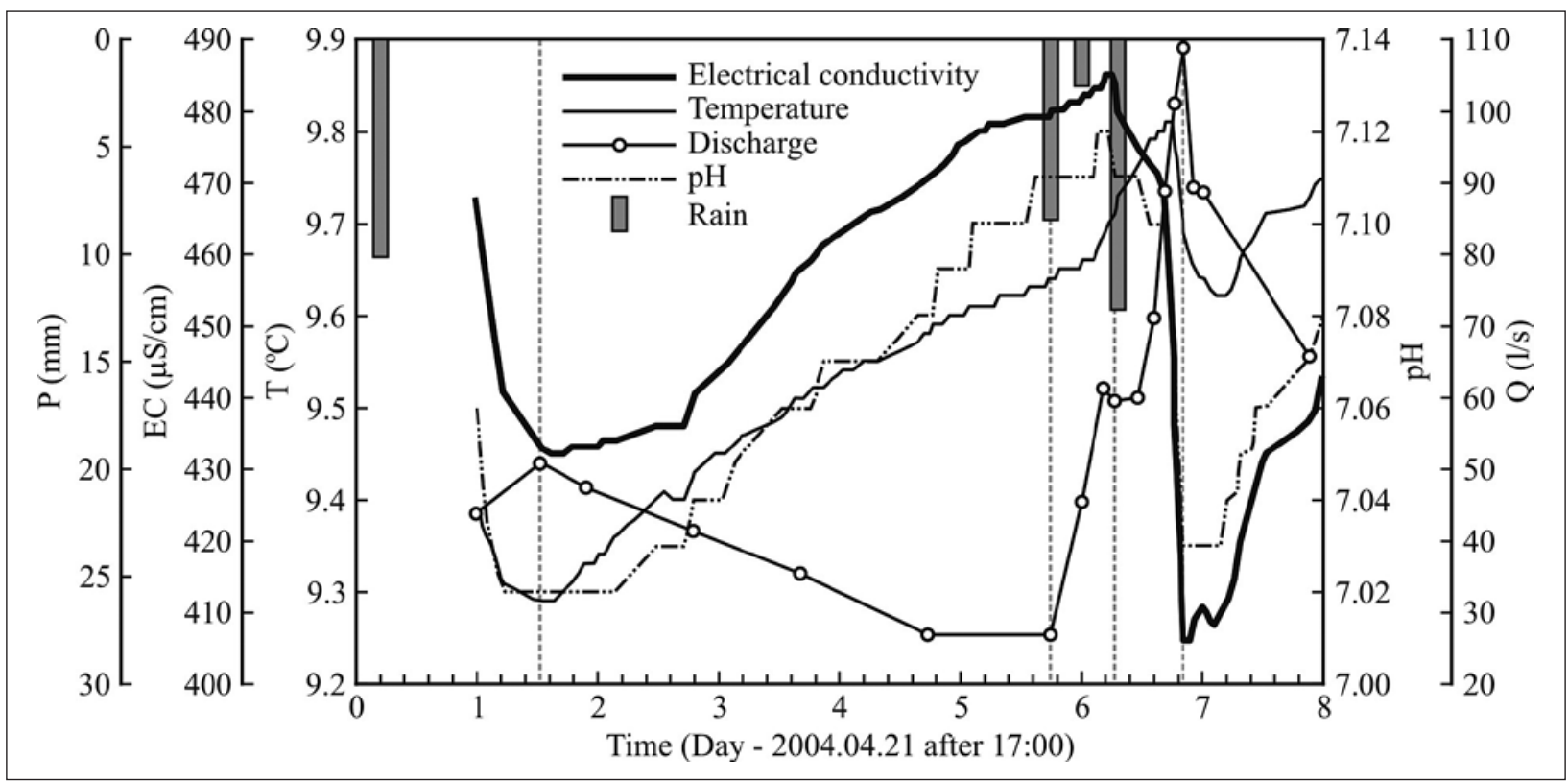

Fig. 5: Chemograph for Döşkaya Spring, April 2004 storm.

I + TOZs II). The mean discharges of the sinking streams were measured as $50.5 \mathrm{l} / \mathrm{s}$ for the BEYs and $49.2 \mathrm{l} / \mathrm{s}$ for the TOZs I + TOZs II (Tab. 1). The discharge of the sinking streams versus that of the Beyyayla and Döşkaya springs were correlated to determine the relationship between them and the contribution of the allogenic-point and autogenic-diffuse and -point recharges. Analyses revealed that the relations were represented by the following equations: $Q_{B E Y}=1.16 Q_{B E Y S}+1.38$ for the Beyyayla aquifer $\left(R^{2}, 0.99\right)$ and $Q_{D O S}=1.058 Q_{\text {TOZSI }+ \text { TOZSII }}+5.46$ for the Döskaya aquifer $\left(R^{2}, 0.98\right)$. The contributions of the allogenic-point recharge to the Beyyayla and Döşkaya spring discharges were calculated as $84.4 \%$ and $86.5 \%$, respectively (Tab. 3). The rest of the discharge came from autogenic diffuse/point recharge on Beyyayla and Döşkaya aquifers. On the other hand, recharge of the Nardin aquifer took place as autogenic diffuse/point recharge.

In addition, Shuster and White (1971) and Quinlan and Ewers (1985) used a 5 - $10 \%$ threshold values that the coefficient of variation of physical and chemical parameters such as temperature, calcium or alkalinity of spring water for characterizing recharge and flow condition in the aquifer. They suggest that the coefficient of variation changes between $5 \%$ and $10 \%$ is characterized diffuse flow and autogenic diffuse/point recharge condition. Conduit flow and allogenic point recharge condition are characterized above the threshold values. The coefficients of variation of temperature, bicarbonate and calcium were calculated in the range of $24.3 \%$ to $43.3 \%$ for the Beyyayla and Döşkaya springs and $4.5 \%$ to $7.1 \%$ for the Nardin spring (Tab. 1). The calculated values of coefficient of variation for Nardin springs is equal or lower than these threshold values. On the other hand, Beyyayla and Döşkaya springs have a few times greater value than the threshold. This indicates that, groundwater flow occurs as conduit flow at Beyyayla and Döşkaya system and diffuse flow at Nardın system. These values also indicate that allogenic recharge dominated in the Beyyayla and Döşkaya system.

\section{STORAGE AND FLOW IN THE HBKS}

In the present study, Maillet's (1905) equation was used for the spring recession analysis. Milanovic (1981) suggest that spring recession analysis and recession coefficient represents the capability of the underground media to release groundwater. The hydrodynamic properties of the media such as storage, effective porosity, can be

\begin{tabular}{lcc}
\hline \multirow{2}{*}{$\begin{array}{l}\text { Name of } \\
\text { sub-system }\end{array}$} & \multicolumn{2}{c}{ Recharge type } \\
\cline { 2 - 3 } & Allogenic point (\%) & Autogenic diffuse/point (\%) \\
\hline Beyyayla & 84.4 & 15.6 \\
\hline Döşkaya & 86.5 & 13.5 \\
\hline Nardin & - & 100 \\
\hline
\end{tabular}

Tab. 3: Contribution of the allogenic point and autogenic diffuse/point recharge on the HBKS subsystems. 
Tab. 4: Results of spring recession analysis of Beyyayla, Döşkaya and Nardın spring.

\begin{tabular}{|c|c|c|c|c|c|c|c|c|}
\hline \multirow{3}{*}{ Parametre } & \multicolumn{2}{|c|}{ Beyyayla Spring } & \multicolumn{4}{|c|}{ Döşkaya Spring } & \multicolumn{2}{|c|}{ Nardin Spring } \\
\hline & \multirow{2}{*}{2003} & \multirow{2}{*}{2004} & \multicolumn{2}{|c|}{2003} & \multicolumn{2}{|c|}{2004} & \multirow{2}{*}{2003} & \multirow{2}{*}{2004} \\
\hline & & & $1^{\text {st }}$ rec & $2^{\text {nd }} \mathrm{rec}$ & $1^{\text {st }} \mathrm{rec}$ & $2^{\text {nd }}$ rec & & \\
\hline$a\left(\right.$ day $\left.^{-1}\right)$ & 0.023 & 0.028 & 0.046 & 0.009 & 0.035 & 0.017 & 0.037 & 0.039 \\
\hline $\mathrm{t}$ (day) & 190 & 196 & 45 & 174 & 69 & 174 & 59 & 87 \\
\hline$V_{t}\left(x 10^{6} m^{3}\right)$ & 0.267 & 0.202 & \multicolumn{2}{|c|}{0.191} & \multicolumn{2}{|c|}{0.546} & 0.806 & 0.860 \\
\hline$V_{d}\left(x 10^{6} \mathrm{~m}^{3}\right)$ & 0.263 & 0.202 & \multicolumn{2}{|c|}{0.141} & \multicolumn{2}{|c|}{0.465} & 0.715 & 0.832 \\
\hline$V_{r}\left(x 10^{6} \mathrm{~m}^{3}\right)$ & 0.003 & 000.1 & \multicolumn{2}{|c|}{0.050} & \multicolumn{2}{|c|}{0.081} & 0.091 & 0.028 \\
\hline$V_{d} / V_{t}(\%)$ & 98.8 & 99.6 & \multicolumn{2}{|c|}{73.6} & \multicolumn{2}{|c|}{85.1} & 88.7 & 96.8 \\
\hline $\mathrm{V}_{\mathrm{r}} / \mathrm{V}_{\mathrm{t}}(\%)$ & 1.2 & 0.4 & \multicolumn{2}{|c|}{26.4} & \multicolumn{2}{|c|}{14.9} & 11.3 & 3.2 \\
\hline
\end{tabular}

$\alpha$ : recession coefficient; $t$ : duration of recession; $\mathrm{V}_{\mathrm{t}}$ : total volume; $\mathrm{V}_{\mathrm{d}}$ : volume of discharge water during recession; $\mathrm{V}_{\mathrm{r}}$ : volume of remain water after recession

estimated by the recession coefficient. High recession coefficient characterizes groundwater storage in cave and channel system where turbulent flow prevails. As opposed to low recession coefficient represents groundwater storage in well connected and partially karstified fractures system (Milanovic 1981).

Thus hydrographs of the springs in the HBKS were evaluated by means of spring recession analysis for the 2003 and 2004 season (Fig. 6). The hydrographs were represented by one recession for the Beyyayla and Nardın springs and two recessions for the Döşkaya spring during the observation period. The coefficients of recession were obtained between 0.0087 and 0.0459 day $^{-1}$ for all springs. The obtained data from recession analysis are given in Tab. 4. The recession coefficient of the Beyyayla and the first recession of the Döşkaya spring indicate that groundwater flows as turbulent flow in well-developed and connected fractures or karstic channels of the aquifers with low storage capacity. In addition, the second recession of the Döşkaya spring represents groundwater that comes from tiny fractures and sandy and sandy-clayey materials deposited in the inactive channels and caves. At this period, the groundwater flow laminar condition has relatively high storage capacity in aquifers of Döşkaya. Hydrograph readings for the other side of the Nardın spring indicate that this aquifer has the low storage capacity and groundwater flows are dispersed in well-developed and connected fractures or karstic channels in its aquifer. In addition, spring recession analysis showed that approximately $60 \%$ of the total water volume in the aquifers were discharged in 45 days. During the recession period Beyyayla, Döşkaya and Nardın spring are discharging its total volume as $98.8 \%-99.6 \%, 73.6 \%-85.1 \%$ and $88.7 \%$ - $96.8 \%$, respectively (Tab. 4).

Besides spring recession analysis and trace tests, hydrogeochemical properties of the groundwater were investigated to characterize flow conditions in the aquifers. Coefficients of variation of physical and chemical parameters of the spring water (in Tab. 1) were compared with Quinlan and Ewers (1985) study. They suggest that groundwater flow in the aquifer could be characterized as a dispersed flow in the case that the value of the coefficient of variation is between $5 \%$ and $10 \%$. If this value is above $10 \%$, groundwater flow could be explained as conduit flow. According to Quinlan and Ewers (1985) classification, groundwater flow occurs as conduit flow at the Beyyayla and Döşkaya aquifers and as dispersed flow at the Nardin aquifer.

\section{DISCHARGE FROM THE HBKS}

$\mathrm{Q}_{\max } / \mathrm{Q}_{\min }$ ratio and coefficient of variations of discharge were calculated to characterize the discharge of karst springs (Tab. 1). The $\mathrm{Q}_{\max } / \mathrm{Q}_{\min }$ ratio for the Beyyayla, Döşkaya and Nardın springs were determined as 345.4, 139.3 , and $\infty$, respectively. The coefficients of variation of spring discharges were obtained as 161.8, 147.7, and 74.9 for the Beyyayla, Döşkaya and Nardın springs. The $\mathrm{Q}_{\max } / \mathrm{Q}_{\min }$ ratio and coefficient of variations of discharge of the Beyyayla and Döşkaya springs have higher values than the Nardin spring due to the allogenic point recharge by sinking streams. These indicate that the Beyyayla and Döşkaya aquifers more rapidly respond to the input, and they are of 'gaining or low-stage underflow' spring type, but the Nardin spring is of "overflow" type according to the classification by Worthington (1991). 


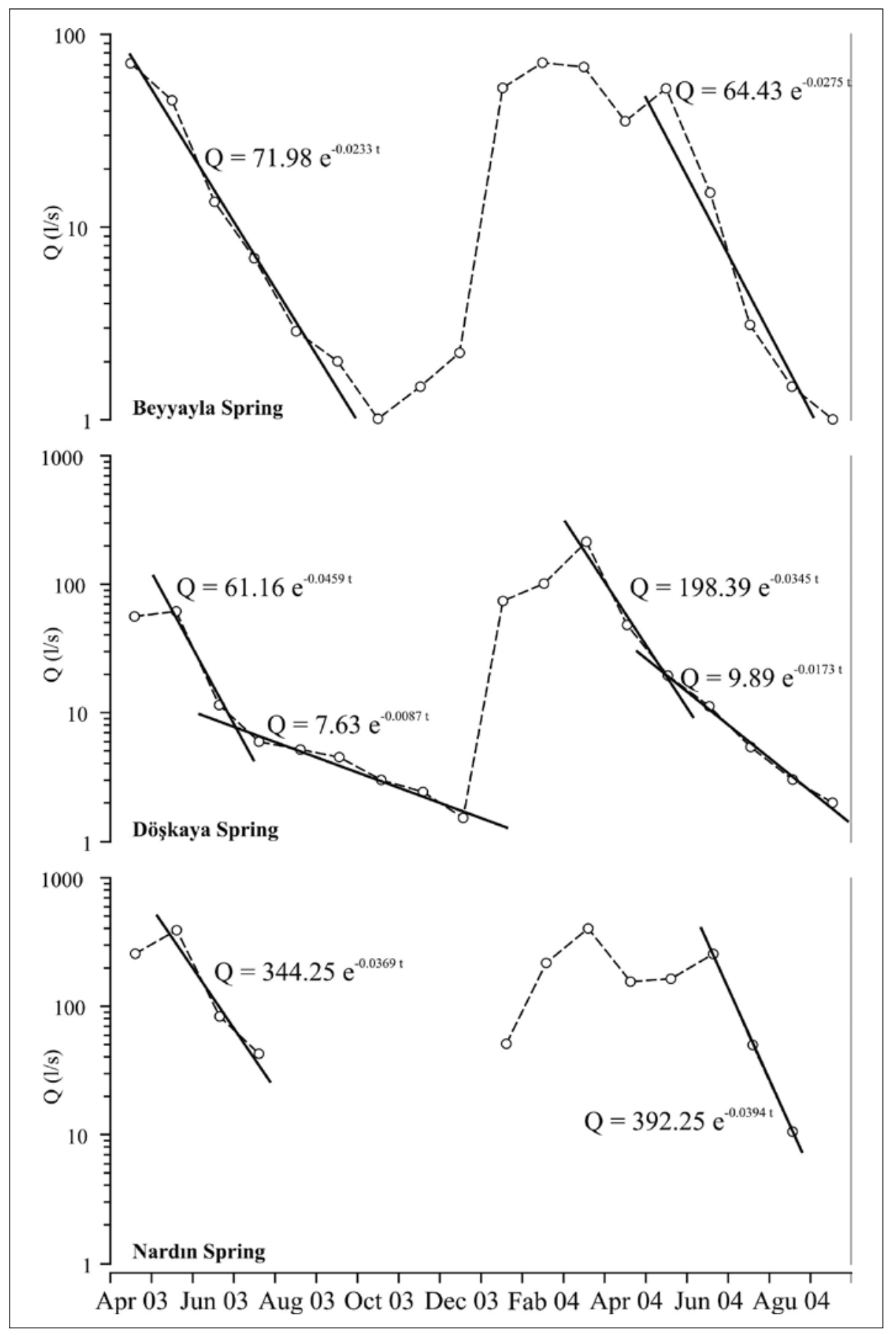

Fig. 6: Recession curve of Beyyayla, Döşkaya and Nardın spring.

\section{CONCEPTUALIZATION OF THE HBKS}

Today the appearance of the HBKS resulted from an energy gradient, which is more important than tectonic, lithological characteristics, and climatic changes in karst evolution. This unique appearance occurred as a result of the distinct morphologic, hydrologic, and hydrodynamic properties of the subsystem. The evaluations presented in previous section suggest that, in spite of its small dimension, the HBKS hydrogeologically can be divided 
into three sub-catchments: the Beyyayla, Döşkaya and Nardin subsystems. These sub-catchments have two different hydrogeological properties, which include factors such as recharge, flow, storage, discharge, and hydrogeochemical characteristics. The Beyyayla and Döşkaya subsystems have similar hydrogeological properties but differ from the Nardin subsystem. The hydrogeological properties of the Beyyayla subsystem are allogenic point and, to a lesser extent, autogenic diffuse/point recharge, conduit flow, low storage capacity, and high variation in rate and chemistry of discharge. The Döşkaya subsystem's aquifer also has the same hydrogeological properties as the Beyyayla subsystem during the first recession time, excepting groundwater flow and storage capacity. The Döşkaya subsystem has conduit-dispersed flow and high storage capacity at the second recession. On the other hand, the Nardin subsystem was characterized with mainly autogenic diffuse recharge and, to a smaller extent, autogenic point recharge, dispersed flow, low storage capacity, and low variation in rate and chemistry of discharge. Based on the conclusions, a conceptual model of the subsystems was proposed and illustrated in Fig. 7.

Variation in energy gradient at the WCAR has lowered the erosion-base exposure of granites, which contributes to the allogenic point recharge of the Beyyayla and Döşkaya subsystems. Sources of allogenic point recharge on the Beyyayla and Döşkaya subsystems are constituted from granites that have extended their drainage basins. Groundwater flow as conduit flow in these subsystems was produced by the genesis of the allogenic point recharge. Shortening of the water-rock interaction time and the dominating mechanical erosion in the Beyyayla and Döşkaya subsystems arise from the highenergy gradient and therefore high groundwater velocity. In addition to this, the existence of the granitic sands at the outlet of the Beyyayla and Döşkaya springs indicates that groundwater flow in well-developed conduits is turbulent in the aquifers. The karst evolution has been controlled by the change in the regional energy gradient and the type of recharge at the Beyyayla and Döşkaya subsystems. At these subsystems, karstification developed in a vertical direction rather than as areal extends as a result of the allogenic point recharge.

On the other hand, the Nardin subsystem differs from the Beyyayla and Döşkaya subsystems because of the deficiency of allogenic point recharge. As a consequence of autogenic diffuse/point recharge on the Nardin subsystem, groundwater has adequate time for waterrock interaction, and it flows as diffuse form. Because of this, karst evolution has been developed vertically and also in areal extends at the Nardin subsystem.

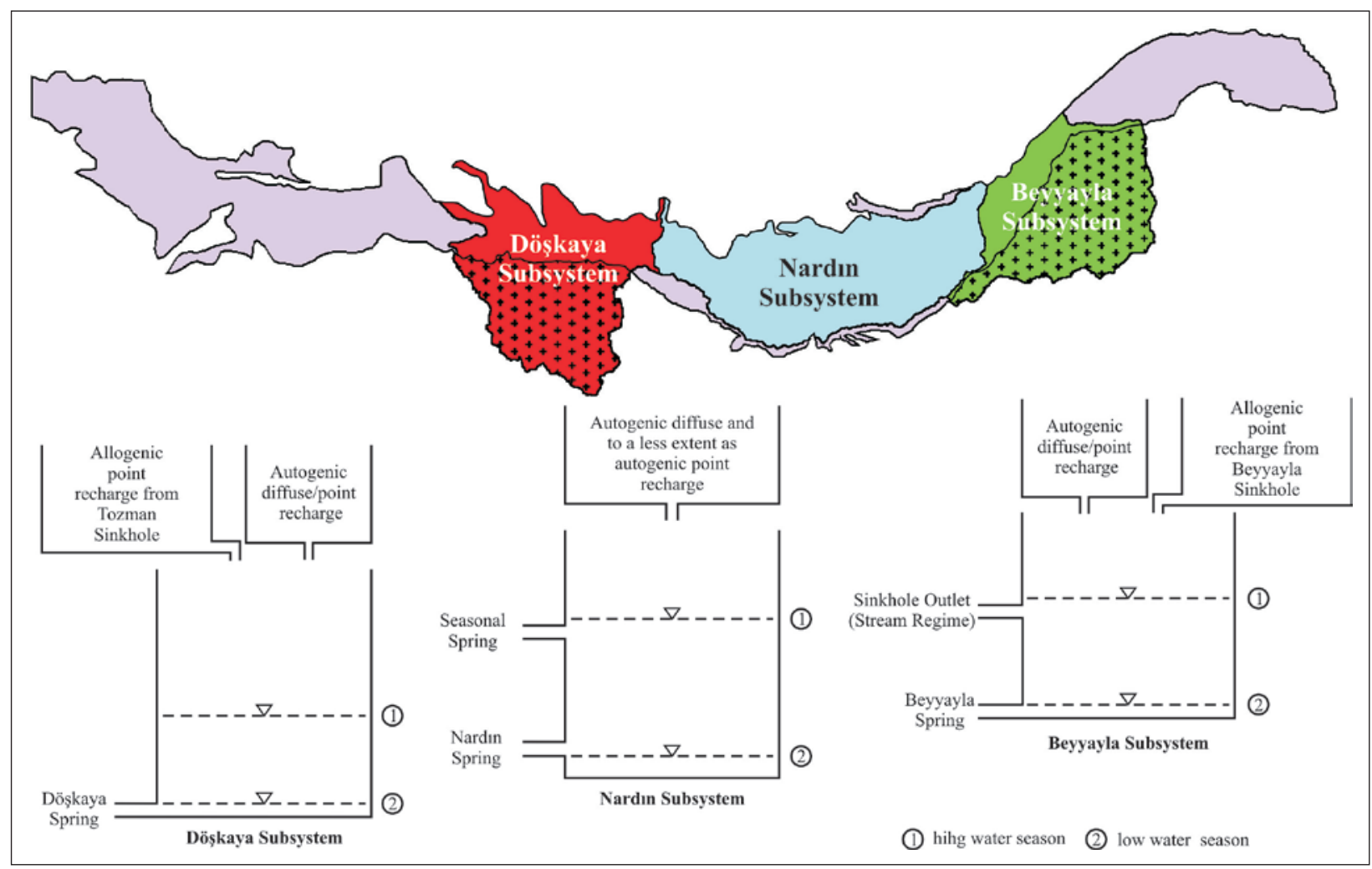

Fig. 7: Conceptual model of the dissected-relict karst aquifers in northwestern Turkey. 


\section{CONCLUSIONS}

This research was conducted on a dissected relict karst aquifer known as the HBKS in the WCAR. The HBKS forms highlands in central Turkey and is shaped like a rectangle with a surface area of $49.5 \mathrm{~km}^{2}$. Modern appearance of karst evolution in the WCAR resulted from an energy gradient, which is more important than tectonic activity, lithologic characteristics of the limestone, and climatic changes. At the initial stage, Jura Age Bilecik Limestone is a single block. Since Oligocene, it outcropped at the continental phase, and erosional faces began to form. At this period, karstification is controlled in the WCAR by tectonic activity, lithological characteristics of the limestone, and climatic changes as well as energy gradient until Quaternary. But changes in the level of the Black Sea, the incision of the Sakarya River, and continental uplift formed sources of energy gradient at the WCAR after the Quaternary. The regional scale variation of energy gradient caused the dissection of Jura Age Bilecik Limestone. Thus, dissected limestone blocks have no hydrologic and hydrogeologic relationships.

Today, in spite of its small dimension, the HBKS hydrogeologically can be divided into three sub-catchments (the Beyyayla, Döşkaya and Nardın subsystems) including aquifer systems with two types of hydrogeological behaviors because of karst evolution in the WCAR. These subsystems have different recharge, flow, storage, and discharge characteristics. The first type of hydrogeological behavior dominates the Beyyayla and Döşkaya subsystems located in the east and west sides of the HBKS. Recharge on these subsystems mainly occurs as allogenic point recharge from sinking streams and, to a lesser extent, as autogenic diffuse/point recharge from the out- crop of Bilecik Limestone. The flow progresses quickly as conduit flow through caves and well-developed conduits in the Beyyayla and Döşkaya subsystems. The spring of the Beyyayla and Döşkaya subsystems produce hydrographs with very sharp peaks as a consequence of the allogenic recharge. The chemical composition of the Beyyayla and Döşkaya springs' water presents a very rapid variation because of the lower residence time for water-rock interaction in the fracture or conduit system during the allogenic recharge time. When the absence of the allogenic recharge on the HBKS, chemical quality of the discharge waters tends to increase due to the longer residence time for water-rock interaction in the fracture or conduit system.

A second type of hydrogeological behavior dominates the Nardin subsystem located in the middle of these subsystems. Recharge occurs as mainly autogenic diffuse and, to some extent as, autogenic point from the outcrop of Bilecik Limestone. The groundwater flow takes place as dispersed flow through well-developed conduits in the Nardin subsystem. In addition, the chemical composition of the Nardin spring's waters presents a slightly low variation because of the relatively great residence time in the aquifer as opposed to the Beyyayla and Döşkaya aquifers. These properties make the HBKS important for urban and irrigation water supply in semiarid regions. The Nardin spring's groundwater provides a good chemical quality for urban supply as opposed to the Beyyayla and Döşkaya springs' groundwater, due to settlements and allogenic point recharge in the drainage areas of Beyyayla and Döşkaya springs

\section{ACKNOWLEDGEMENTS}

This study was carried out within the frameworks of Research Center Office of Hacettepe University (Project Code: 02.0.0602.009). The authors also grateful to Esin Öncel and Füsun Muslu for the chemical analyses at Water Chemistry Laboratories of Hacettepe University, and Türkay Coşkuner, Devrimer Yavuz, Bület Topuz and
Hüseyin Karakuş for their considerable help during some field trips and drawings. Nathalie Dörfliger and Zoran Stevanovic are thanked for the valuable review comments and suggestions which improved the final form of the manuscript. 


\section{REFERENCES}

Abigail, L.L., Screaton, E.J., Martin, J.B. \& V. BaillyComte, 2012: Interactions of diffuse and focused allogenic recharge in an eogenetic karst aquifer (Florida, USA).- Hydrogeology Journal, 20, 767-781.

Aksay, A. \& M. Duru, 2002: 1/100.000 Scale Geological Maps of Turkey, Adapazarı H24 sheet.- Genera Directorate of Mineral Research and Exploration (MTA), Pub. No: 37.- Ankara.

Akyazı, M., Toprak, O., Erdoğan, T., Karabasoğlu, A. \& T.S. Ursavas, 2001: Mesozoic stratigraphy of Bilecik region (in Turkish). Cumhuriyet University Journal of Earth Sciences, 18, 27-46.

Altıner, D., Koçyiğit, A., Farinacci, A., Nicosia, U. \& M.A. Conti, 1991: Jurassic - Lower Cretaceous stratigraphy and paleogeographic evolution of the southern part of northwestern Anatolia (Turkey).- Geologica Romana, 27, 13-80.

APHA/AWWA/WPCF, 1989: Standard Methods for the Estimation of Water and Wastewater.- $17^{\text {th }}$ edition, American Public Health Association, Washington, D.C.

Atkinson, T.C. 1977: Diffuse flow and conduit flow in limestone terrain in the Mendip Hills, Somerset (Great Britain).- Journal of Hydrology, 35, 93-110.

Aydin, H., 2005: Investigation of morphology - hydrogeology relations in Harmanköy - Beyyayla (Bilecik) karst system.- PhD Thesis. Institute of Graduate Studies, Hacettepe University, Ankara, pp. 255.

Bagarić, I., 1978: Determination of storage and transportation characteristics of karst aquifers.- In: Milanović, P.T. (eds) Karst Hydrogeology. Water Resources Publications, pp. 434, Littleton, CO, USA.

Bayarı, C.S., Özyurt, N.N., Öztan, M., Bastanlar, Y., Varınlıoğlu, G., Koyuncu, H., Ülkenli, H. \& S. hamarat, 2011: Submarine and coastal karstic groundwater discharges along the Southwestern Mediterranean coast of Turkey.- Hydrogeology Journal, 19, 399-414.

Bear, J., 1979: Hydraulics of Groundwater.- McGraw-Hill Companies, pp. 592, New York.

Berkaloff, E., 1967: Limite de validité des formules courantes de tarissement de debit.- Chronique d'Hydrogéologie, 10, 31-41.

Bosak, P., 1981: Terminology and study of ancient karst phenomena.- Česky kras, 6, 58-66.

Chen, Z., Linhua, S. \& M.M. Sweeting, 1986: The pinnacle karst of Stone Forest, Lunan, Yunnan, China, an example of a subjacent karst.- Paterson, K. \& M.M. Sweeting (eds) New Directions in Karst. Geobooks, pp. 597-607, Norwich.
Dörfliger, N., Fleury, P., B. Ladouche, 2009: Inverse modeling approach to allogenic karst system characterization.- Ground Water, 47, 414-426.

Dreiss, S.J. 1989: Regional scale transport in a karst aquifer: 1. Component separation of spring flow hydrographs.- Water Resources Research, 25, 117-125.

Ekmekçi, M. 2003: Review of Turkish karst with emphasis on tectonic and paleogeographic controls.- Acta Carsologica, 32, 205-218.

Ekmekçi, M. \& L. Nazik 2004: Evolution of Golpazarı - Huyuk karst system (Bilecik): Indications of tectonic and climatic controls.- International Journal of Speleology, 33, 49-64.

Elhatip, H. 1997: The influence of karstic features on environmental studies in Turkey.- Environmental Geology, 31, 27-33.

Eroskay, S.O. \& G. Günay, 1979: Tecto-genetic classification and hydrogeological properties of the karst regions in Turkey.- Proceedings International Seminar on Karst Hydrogeology, Oct. 9-19, 1979, pp. 1-43, Oymapinar, Antalya.

Ford, D.C. \& P.W. Williams, 1989: Karst Geomorphology and Hydrology.- Unwin Hayman, pp. 601, London.

Gedik, I. \& A. Aksay, 2002: 1/100.000 Scale Geological Maps of Turkey, Adapazari H25 sheet.- Genera Directorate of Mineral Research and Exploration (MTA), Pub. No: 38.- Ankara.

Geyer, T., Birk, S., Licha, T., Liedl, R. \& M. Sauter, 2007: Multitracer test approach to characterize reactive transport in karst aquifers.- Ground Water, 45, 3645.

Göncüoğlu, M.C. (ed.), Turhan, N., Şentürk, S., Uysal, S. \& A. Özcan, 1996: The geological features of the structural units between Nallihan - Saricakaya at Middle Sakarya.- Geological Studies Division of General Directorate of Mineral Research and Exploration (MTA), Report No: 10094, Ankara.

Göppert, N. \& N. Goldscheider, 2008: Solute and colloid transport in karst conduits under low- and highflow conditions.- Ground Water, 46, 61-68.

Granit, Y. \& H. Titant, 1960: Observations préliminaires sur le Jurassique de la reginon de Bilecik (Turquie).Lab. De Geol., Faculté des Sciences, Dijon.

Halihan, T., Wicks, C.M. \& J.F. Engeln, 1998: Physical response of a karst basin to flood pulses: Example of the Devil's Icebox cave system (Missouri, USA).Journal of Hydrology, 204, 24-36.

Hess, J.W. \& W.B. White, 1988: Storm response of the karstic carbonate aquifer of south central Kentucky.- Journal of Hydrology, 99, 235-252. 
Jakucs, L., 1959: Neue methoden der hohlenforschung in ungarn und ihre ergebnisse, Auffinden von hohlen aus Indizien.- Hydrologie, 10, 88-98.

Király, L., 2002: Karstification and groundwater flow.- In: Gabrovsek, F. (eds) Proceedings of the Conference on Evolution of Karst: From Prekarst to Cessation. Institute of ZRC-SAZU, pp. 155-190, Postojna-Ljubljana.

Király, L. \& G. Morel, 1976: Etude de régularisation de l'Areuse par modèle mathématique.- Bulletin d'Hydrogéologie, 1, 19-36.

Kislov, A. \& P. Toropov, 2007: East European river runoff and Black Sea and Caspian Sea level changes as simulated within the Paleoclimate modeling intercomparison project.- Quaternary International, 167-168, 40-48.

Lee, E.S. \& N.C. Krothe, 2001: A four component mixing model for water in a karst terrain in South Central Indiana, USA: Using Solute Concentration and Stable Isotopes as Tracers.- Chemical Geology, 179, 129-143.

Magaldi, D. \& U. Sauro, 1982: Landforms and soil evolution in some karstic areas of the Lessini Mountains and Monte Baldo (Verona, Northern Italy).- Geografia Fisica e Dinamica Quaternaria, 5, 82-101.

Maillet, E., 1905: Mécanique et physique du globe.- Essais d'hydraulique souterraine et fluviatile. pp. 4, Hermann, Paris.

Mangin, A., 1973: Sur la dynamique des transferts en aquif' ere karstique.- In: Viladimir P. (eds) Proceedings of the $6^{\text {th }}$ International Congress on Speleology, Vol: 6, pp. 157-162, Olomouc, CSSR.

Martin, J.B. \& R.W. Dean, 1999: Temperature as a natural tracer of short residence times for groundwater in karst aquifers.- In: Palmer, A.N., Palmer, M.V. \& I.D. Sasowsky (eds), Karst Modeling, Proceedings of the Symposium. Karst Waters Institute Special Publication 5, 236-242, Charlottesville, Virginia.

Martin, J.B. \& R.W. Dean, 2001: Exchange of water between conduits and matrix in the Floridan aquifer.Chemical Geology, 179, 145-165.

Martin, J.B. \& E.J. Screaton, 2001: Exchange of matrix and conduit water with examples from the floridan aquifer, in U.S.- In: Kuniansky, E.L. (ed), U.S. Geological Survery Karst Interest Group Proceedings, Water-Resources Investigations Report 01-4011, 38-44, Florida.

Milanovic, P.T., 1981: Karst Hydrogeology.- Water Resources Publications, pp. 283, Littleton, Colorado.

Monroe, W.H., 1976: The Karst Landforms of Puerto Rico.- United States Government Printing Office, pp. 69, Washington, D.C.
Nazik, L., Tork, K., Acar, C., Özel, E., Mengi, H., Aksoy, B., Tuncer, K., Güner, İ.N., Ekmekçi, M. \& A. Başal, 2001: The natural caves at Central Sakarya Basin (east of Eskisehir and Bilecik).- Geological Studies Division of General Directorate of Mineral Research and Exploration (MTA), Report No: 10420, Ankara.

Özyurt, N.N., 2008: Analysis of drivers governing temporal salinity and temperature variations in groundwater discharge from Altug Submarine Karst Cave (Kas-Turkey).- Environmental Geology, 54, 731736.

Özyurt, N.N. \& C.S. Bayarı, 2008: Temporal variation of chemical and isotopic signals in major discharges of an alpine karst aquifer in Turkey: Implications with respect to response of karst aquifers to recharge.Hydrogeology Journal, 16, 297-309.

Quinlan, J.F. \& R.O. Ewers, 1985: Groundwater flow in limestone terrains; strategy rationale and procedure for reliable and efficient monitoring of ground water quality in karst areas.- In: National Water Well Association (eds) $5^{\text {th }}$ International Symposium on Aquifer Restoration and Groundwater Monitoring, pp. 197-234, Columbus, Ohio.

Quinlan, J.F., Davies, G.J., Jones, S.W. \& P.W., Huntoon, 1996: The applicability of numerical models to adequately characterize ground-water flow in karstic and other triple-porosity aquifers.- In: Ritchy, J.D. \& J.O. Rumbaugh (eds), Subsurface Fluid Flow (Groundwater and Vadose Zone) Modeling, American Society for Testing and Materials, pp. 114-133, ASTM STP 1288.

Raeisi, E. \& G.H. Karami, 1997: Hydrochemographs of Berghan karst spring as indicator of aquifer characteristics.- Journal of Cave and Karst Studies, 59, 112-118.

Saner, S., 1980: Paleogeography and post-depositional interpretation of Jurassic basins at Mudurnu- Göynük basin.- Geological Bulletin of Turkey, 23, 39-52.

Schuster, E.T. \& W.B. White, 1971: Seasonal fluctuations in the chemistry of limestone springs: a possible means for characterizing carbonate aquifers.- Journal of Hydrology, 14, 93-128.

Screaton, E.J., Martin, J.B., Ginn, B. \& L. Smith, 2004: Conduit properties and karstification in the unconfined Floridan Aquifer.- Ground Water, 42, 338-346.

Shuster, E.T. \& W.B. White, 1971: Seasonal fluctuations in the chemistry of limestone springs: a possible means for characterizing carbonate aquifers.- Journal of Hydrology, 14, 93-128. 
Smart, P.L. \& S.L. Hobbs, 1986: Characterization of carbonate aquifers: A conceptual base.- In: National Water Well Association (eds) Proceedings of Environmental Problems in Karst Terranes and Their Solutions, pp. 1-14, Bowling Green, Kentucky.

State Meteorological Organization of Turkey, 2012: Official Statistics (Statistic data of the province and districts).- [Online] Available from: http://dmi. gov.tr/veridegerlendirme/il-ve-ilceler-istatistik. aspx?m=BILECIK [Accessed: $12^{\text {nd }}$ April 2012].

Svitoch, A.A., Selivanov, A.O. \& T.A. Yanina, 2000: Paleohydrology of the Black Sea Pleistocene Basins.Water Resources, 27/6, 594-603.

Şengör, A.M.C., Görür, N. \& F. Şaroğlu, 1985: Strike slip faulting and related basin formation in zones of tectonic escape: Turkey as a case study.- In: Biddle, K.T. \& N. Christie-Blick (eds), Strike-slip Deformation, Basin Formation, and Sedimentation. Society of Economic Paleontologists and Mineralogists, Special Publication, 37, 227-264.

Şensoy, S., Demircan, M., Ulupunar, U. \& İ. Balta, 2008: Climate of Turkey.- [Online] Available from: http:// www.dmi.gov.tr/files/en-US/climateofturkey.pdf [Accessed: $15^{\text {th }}$ January 2011].

Ternan, J.L., 1972: Comments on the use of a calcium hardness variability index in the study of carbonate aquifers, with reference to the central Pennines, England.- Journal of Hydrology, 129, 87-108.

Tuncer, K., 2004: Karst geomorphology of the Sakarya river, Göynük stream and Çatak stream.- PhD Thesis, Institute of Social Science Istanbul University, Istanbul, pp. 250.
Valdes, D., Dupont, J.P., Massei, n., Laignel, B. \& J. Rodet, 2005: Analysis of karst hydrodynamics through comparison of dissolved and suspended solids' transport.- Compte Rendus Geoscience, 337, 13651374.

White, W.B., 1969: Conceptual models for limestone aquifers.- Groundwater, 7(3), 15-21.

White, W.B. 2003: Conceptual models for karstic aquifers.- [Online] Available from: http://www.speleogenesis.info/pdf/SG1/SG1_artId2.pdf [Accessed: $14^{\text {th }}$ April 2012].

White, W.B. \& V.A. Schmidt, 1966: Hydrology of a karst area in east - central West Virginia.- Water Resources Research, 2, 549-560.

Wicks, C.M., 1997: Origins of groundwater in a fluviokarst basin; Bonne Femme Basin in central Missouri, USA.- Hydrogeology Journal, 5, 89-96.

Worthington, S.R.H., 1991: Karst hydrogeology of the Canadian Rocky Mountains.- PhD Thesis, McMaster University, Hamilton, Ontario, pp. 227.

Worthington, S.R.H., 1999: A comprehensive strategy for understanding flow in carbonate aquifers.- In: Palmer, A.N., Palmer, M.V. \& I.D. Sasowsky (eds) Karst Modeling. Special Publication No. 5, Karst Waters Institute, pp. 30-37, Charlottesville, Virginia. 